young children in our community at the present time. After the first four weeks of life good antibody responses can be expected. It is also possible that in some years R.S.V. recedes in importance as a cause of respiratory infection and that adenovirus, influenza, and other viruses then play a bigger part. Finally there is apparently no close antigenic relationship between measles and R.S.V., though this point needs further investigation.

\section{Summary}

-A serological investigation has been carried out on paired sera from 148 children over the last three years in Newcastle upon Tyne. The great majority of these children had serious infection of the lower respiratory tract, mainly bronchiolitis and pneumonia. Serological evidence is presented that about $60 \%$ of severe respiratory infections in the children are due to respiratory syncytial virus. The immunological responsiveness of infants to R.S.V. infection increases with age ; this is directly related to the decrease in maternal antibody, which disappears by 3 months and is replaced by acquired antibody. Few of the older children showed antibody responses, and this coincided with high acquired antibody titres to R.S.V. Evidence is presented which suggests that an antigenic relationship between measles and R.S.V. is unlikely.

Professors S. D. M. Court and C. A. Green have been closely associated with the investigation. The hospitals taking part in the survey were : Royal Victoria Infirmary and Babies' Hospital, the Fleming Memorial Hospital, Walkergate Hospital, and Newcastle
General Hospital, and we are indebted to Drs. E. G. Brewis, G. Davison, W. D. Elliott, R. H. Jackson, and F. J. W. Miller for free access to patients under their care and for the use of clinical records. Our thanks are also due to Dr. E. G. Knox, Miss J. McQuillin, and Miss A. White for their assistance in a variety of ways. This work has been partly aided by a grant from the Scientific and Research Subcommittee, for which we are grateful.

\section{REFERENCES}

Andrew, J. D. and Gardner, P. S. (1963). Brit. med. 7., 2, 1447.

Chanock, R. M., Hyun, W. K., Vargosko, A. J., Deleva, A., Johnson, K. M.; Cumming, C., and Parrott, R. H. (1961). §. Amer. med. Ass., 176, 647.

Enders, J. F., McCarthy, K., Mitus, A., and Cheatham, W. J. (1959). New Engl. \%. Med.; 261, 875.

Fulton, F., and Dumbell, K. R. (1949). 7. gen. Microbiol., 3, 97.

Gardner, P. S., Stanfield, J. P., Wright, A. E., Court, S. .D. M., and Green, C. A. (1960). Brit. med. F, 1, 1077 .

Hambling, M. H (1964). Ibid., 1, 1223 .

Holzel, A., Parker, L., Patterson, W. H., White, L. L. R., Thompson, K. M., and Tobin, J. O'H. (1963). Lancet, 1, 295.

Jensen, K. E. (1962). In American Review of Respiratory Disease, Conference on Newer Respiratory Disease Viruses, p. 194.

Johnson, K. M., Chanock, R. M., Rifkind, D., Kravetz, H. M., and Knight, V. (1961). F. Amer. med. Ass., 176,'663.

Kravetz, H. M., Knight, V., Chanock, R. M., Morris, J. A., Johnson, K. M., Rifkind, D., and Utz, J. P. (1961). Ibid., 176, 657.

McClelland, L., Hilleman, M. R., Hamparian, V. V.; Ketler, A., Reilly, C. M., Cornfeld, D., and Stokes, J. (1961). New Engl. ఫ̈. Med., 264, 1169.

Moss, P. D., Adams, M. O., and Tobin, J. O'H. (1963). Lancet, 1, 298.

Parrott, R. H., Vargosko, A. J., Hyun, W. K., Cumming, C., Turner, H., Huebner, R. J., and Chanock, R. M. (1961). J. Amer. med. Ass., 176, 653 .

Sandiford, B. R., and Spencer, B. (1962). Brit. med. Y., 2, 881.

Smith, R. T. (1960). In Ciba Foundation Symposium on Cellular Aspects of Immunity, edited by G. E. W. Wolstenholme and M. O'Connor, p. 348. Churchill, London.

\title{
Folate Deficiency in Acute Tropical Sprue
}

\author{
W. O’BRIEN,* M.D., M.R.C.P. ; N. W. J. ENGLAND,* M.B., B.SC., M.R.C.P.ED., M.C.PATH.
}

Brit. med. F., 1964, 2, 1573-1575

Anaemia has long been recognized as a feature of tropical sprue. Manson (1879-80) wrote that when the disease is of some standing the patient is anaemic and sometimes the anaemia is profound. Thin (1897) noticed that the anaemia closely resembled pernicious anaemia, and Mackie and Fairley (1929) found megaloblasts at necropsy in the limb bones of two patients. Anaemia has been particularly prominent in the descriptions of sprue from the Caribbean, where the syndrome appears to have been prevalent in a population whose nutritional state was precarious. Rodriguez-Molina (1939) found macrocytic anaemia in 90 out of 100 patients, and Perez-Santiago and Butterworth (1957) described frank megaloblastic change in $71 \%$ and mild megaloblastic change in a further $23 \%$ of bone-marrows taken from another large series of Puerto Rican patients with tropical sprue. On the other hand, tropical sprue in British soldiers has not been associated with such a high incidence of anaemia. Macrocytic anaemia was reported in under a quarter of such patients in India. Marriott (1945), however, stated that though a sprue-like syndrome was seen in both British and Indian troops anaemia was almost confined to the Indians. Gardner (1960) thought that the incidence of anaemia merely reflected the duration of the disorder and the previous nutritional state of the patient.

Fairley (1932) found that the megaloblastic anaemia of tropical sprue responded well to liver. Rhoads and Miller (1934) and Castle et al. (1935) also demonstrated a full response

\footnotetext{
* Lieutenant-Colonel, R.A.M.C., British Military Hospital, Singapore.
}

but warned that the dose of liver required may be much larger than that needed in pernicious anaemia. Spies et al. (1946) and Suárez et al. (1947) reported a spectacular haematological response to folic acid.

Low serum vitamin- $B_{12}$ levels were reported by PerezSantiago and Butterworth (1957) and confirmed by others. Though there might be a moderate rise in these levels after a haematological response to folic acid, in many patients the serum vitamin- $\mathrm{B}_{12}$ level remained low, often in the range seen in pernicious anaemia. Using small doses of folic acid and vitamin $\mathrm{B}_{12}$ Sheehy et al. (1961b) found that some patients would not respond to folic acid but responded to vitamin $B_{12}$. Malabsorption of vitamin $B_{12}$ was demonstrated by RodriguezRosado and Sheehy (1961) and Rivera and Bernabe Preda (1962). Sheehy et al. (1961a) concluded that malabsorption of vitamin $B_{12}$, a low serum level, and a haematological response to that vitamin constituted evidence of vitamin- $\mathrm{B}_{12}$ deficiency in tropical sprue.

Mollin (1961), reporting on work jointly undertaken by him and Dr. C. C. Booth, described cases with chronic tropical sprue, severe megaloblastic anaemia, gross malabsorption of vitamin $B_{12}$, and a serum vitamin- $B_{12}$ level in the range seen in pernicious anaemia. There was a haematological response to folic acid, but vitamin $B_{12}$ malabsorption and the low serum level remained unaffected. One patient later had a haematological relapse with evidence of damage to the central nervous system. There was a satisfactory response to vitamin $\mathbf{B}_{12}$, though initially this was somewhat slower than in uncom- 
plicated vitamin- $B_{12}$ deficiency, which suggested that there was also some degree of folic-acid deficiency.

The significance of low serum vitamin- $B_{12}$ levels in some patients with intestinal malabsorption is open to question. Mollin and Ross (1954) described cases with megaloblastic anaemia and low serum vitamin- $B_{12}$ levels which failed to respond to vitamin $B_{12}$ but responded to folic acid. Later they found that in some patients with megaloblastic anaemia the serum vitamin- $B_{12}$ levels might be 60-140 $\mu \mu \mathrm{g} . / \mathrm{ml}$. and yet the absorption of vitamin $\mathrm{B}_{12}$ be normal (Mollin and Ross, 1957). These patients responded to folic acid better than to vitamin $B_{12}$, and when the anaemia was corrected with folic acid the serum vitamin- $B_{12}$ levels returned to normal.

In this paper we present the results of haematological investigation of 40 patients seen in Singapore during 1962-4 with acute tropical sprue. This work was undertaken as part of the Wellcome Trust study on tropical megaloblastic anaemia. ${ }^{1}$

\section{Methods}

The haematological methods were those described by Dacie (1956). The level of serum folate activity was estimated by Dr. D. L. Mollin at the Hammersmith Hospital by microbiological assay using Lactobacillus casei (Waters and Mollin, 1961). Serum vitamin-B $B_{12}$ levels were also estimated by Dr. Mollin by microbiological assay, using Euglena gracilis (Hutner et al., 1956). Vitamin-B $B_{12}$ absorption was tested by the faecalexcretion method (Heinle et al., 1952), and the results were confirmed by a scintillation count over the liver after a week (Glass et al., 1954). Intrinsic factor (Lederle) was given with a dose of $0.5 \mu \mathrm{g}$. of ${ }^{58} \mathrm{Co}$-labelled vitamin $\mathrm{B}_{12}$ containing $0.5 \mu \mathrm{c}$ of ${ }^{58} \mathrm{Co}$. Faecal-fat estimations were carried out by the wet method of van de Kamer et al. (1949) ; barium-meal examination of the small intestine was performed using Micropaque, and an augmented histamine gastric test meal by the method of Kay (1953). D-Xylose absorption was estimated by measuring the percentage urinary excretion in five hours following an oral dose of $5 \mathrm{~g}$. (Santini et al., 1961). Jejunal biopsies were taken with a Crosby capsule (Crosby and Kugler, 1957).

Patients Studied.-There were 21 men and 19 women in the series. The clinical features were typical of acute tropical sprue. There was diarrhoea with the passage of from two to eight lightcoloured, foul-smelling stools of the consistency of porridge. Patients complained of anorexia, asthenia, glossitis, and considerable loss of weight. The latter symptoms often preceded diarrhoea by several months. Diarrhoea had been present for a mean of 3.2 months, and only two patients had suffered from this symptom for more than six months. The results of gastro-intestinal investigation of these patients is shown in Table I.

TABLE I.-Gastro-intestinal Investigation of 40 Patients with Tropical Mean daily faecal fat excretion D-Xylose excretion in 5 hours Absorption ${ }^{58}$ Co-Vitamin $\mathrm{B}_{12}$

Dissecting Microscope Thickened leaves Convolutions

$$
\begin{aligned}
& \text { Sprue }
\end{aligned}
$$

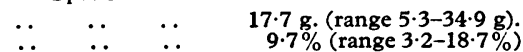

$$
\begin{aligned}
& \text { fejunal biopsy } \cdots \quad 13.0 \% \text { (range } 0.0-33.0 \% \text { ) } \\
& 7 \text { Normal Histology } \\
& \begin{array}{l|llr}
19 & \begin{array}{l}
\text { Minor abnormal change } \\
\text { Partial villous atrophy }
\end{array} & \ldots & 7 \\
& \ldots & 27
\end{array}
\end{aligned}
$$

\section{Results}

If the lower normal limit of haemoglobin be accepted as $12.5 \mathrm{~g} . / 100 \mathrm{ml}$. for men and $11.5 \mathrm{~g} . / 100 \mathrm{ml}$. for women, then 9 men and 13 women were anaemic. Three out of the 21 men had haemoglobin concentrations ranging from 5.2 to $10 \mathrm{~g} . / 100$ ml. and 11 women had haemoglobin concentrations of 3.7 to

1 The participants in the Wellcome Trust study on tropical megaloblastic anaemia are as follows : Chairman, Professor J. V. Dacie ; Scientific Secretary, Dr. D. L. Mollin ; Secretary, Dr. Peter Williams ; Professor S. Baker (Vellore) ; Dr. C. C. Booth (Ham nersmith Hospital); Lieutenant-Colonel N. W. J. England (Singapore); Dr. Henry Foy (Nairobi); Lieutenant-Colonel W. O'Brien (Singapore).

10 g. $/ 100 \mathrm{ml}$. Eleven men and 17 women had red-cell counts of under 4,000,000/c.mm.

There was evidence of megaloblastic change in the sternalmarrow films of every patient. Twenty-two showed mild megaloblastic change and 18 frank megaloblastic change. By mild megaloblastic change we mean the presence of giant metamyelocytes with some erythroid cells displaying a relatively fine nuclear pattern and the persistence of the nucleolus-associated chromatin. Megaloblastic change was more severe in women. Frank megaloblastic change was found in 11 out of 19 women and in 7 out of 21 men. There was a close correlation between the degree of megaloblastosis and the severity of the anaemia. Thus in all patients with a frankly megaloblastic marrow the red-cell count was below 3,000,000/c.mm.

The level of serum folate activity was below $4 \mathrm{~m} \mu \mathrm{g} . / \mathrm{ml}$. in all 39 patients tested and below $2 \mathrm{~m} \mu \mathrm{g}$. $/ \mathrm{ml}$. in 23 . In two patients with severe megaloblastic anaemia the level of serum folate activity was $3.2 \mathrm{~m} \mu \mathrm{g} . / \mathrm{ml}$. and $4 \mathrm{~m} \mu \mathrm{g} . / \mathrm{ml}$. respectively. Both these patients were iron-deficient and the serum folate activity fell after iron was given.

The level of serum vitamin $\mathbf{B}_{12}$ was below $200 \mu \mu \mathrm{g} . / \mathrm{ml}$. in 26 patients $(65 \%)$. The level of serum vitamin $B_{12}$ in 150 controls was below $200 \mu \mu \mathrm{g} . / \mathrm{ml}$. in seven $(4.7 \%)$. The level was below $140 \mu \mu \mathrm{g} . / \mathrm{ml}$. in 16 patients. The mean serum vitamin $B_{12}$ in 10 patients who could absorb less than $10 \%$ of ${ }^{58} \mathrm{Co}$-labelled vitamin $\mathrm{B}_{12}$ was $120 \mu \mu \mathrm{g} . / \mathrm{ml}$. compared with a level of $225 \mu \mu \mathrm{g} . / \mathrm{ml}$. for those who could absorb more than $10 \%$. After treatment the rise in serum vitamin $B_{12}$ was proportional to the recovery of the power to absorb vitamin $\mathbf{B}_{12}$.

The results of haematological investigation to these patients are shown in Table II. There was little correlation between the degree of intestinal malabsorption and the severity of the megaloblastic anaemia. Thus there were two patients with severe megaloblastic anaemia (haemoglobin 5.2 and 4.1 g./100 ml.), normal jejunal biopsies, and laboratory evidence of only mild malabsorption.

In megaloblastic anaemia, whether due to deficiency of folate or of vitamin $B_{12}$, a haematological response may be given to the usual therapeutic doses of either of these two vitamins, but if a dose of $200 \mu \mathrm{g}$. of folic acid is used a haematological response will occur only if folate deficiency is present. Accordingly 16 patients with megaloblastic anaemia were treated with $200 \mu \mathrm{g}$. of folic acid by intramuscular injection daily for two to four weeks. Eleven of these patients gave a full haematological response (see Table III) as shown by an adequate reticulocytosis and a subsequent rise in haemoglobin and red-cell count. In all but one of these patients the serum folate activity had risen to $32 \mathrm{~m} \mu \mathrm{g} . / \mathrm{ml}$. 28 days after the beginning of treatment. Five patients had a suboptimal response: in two this was due to an associated iron deficiency, and a full response followed iron therapy; in the other three, all of whom had severe megaloblastic anaemia though there was an adequate reticulocytosis, the rise in haemoglobin and red cells was suboptimal. In the latter three patients the serum folate activity had risen to only $1.6,2.5$, and $5.6 \mathrm{~m} \mu \mathrm{g} . / \mathrm{ml}$. by the twenty-eighth day. In one of these patients the lack of response may have been due to an associated vitamin- $B_{12}$ deficiency, but the serum vitamin- $B_{12}$ levels in the other two patients were normal.

Five patients with megaloblastic anaemia were treated with $1 \mu \mathrm{g}$. of vitamin $\mathrm{B}_{12}$ daily by intramuscular injection for two to four weeks. There was no haematological response.

$$
\begin{aligned}
& \text { TABLE II.-Haematological Investigation of } 40 \text { Patients with Tropical } \\
& \text { Sprue } \\
& \text { A. Mildly megaloblastic marrow (mean values in } 22 \text { patients) } \\
& \text { Haemoglobin } \quad .13 .3 \mathrm{~g} . / 100 \mathrm{ml} \text { (range } 10-15 \mathrm{~g} / 100 \mathrm{ml} \text { ) } \\
& \text { Red-cell count } \quad \because 4,000,000 \text { c.mm. (range 3,100,000-5,300,000/c.mm.) } \\
& \text { Serum folate... } \ldots 2.2 \mathrm{~m} \mu \mathrm{g} . / \mathrm{ml} \text {. (range 0.6-3.7 } \mathrm{m} \mu \mathrm{g} . / \mathrm{ml} \text {.) } \\
& \text { B. Frankly megaloblastic marroro (mean values in } 18 \text { patients) } \\
& \text { Haemoglobin } \quad . \quad 8 \mathrm{~g} . / 100 \mathrm{ml} \text {. (range } 3 \cdot 7-12 \cdot 1 \mathrm{~g} / 100 \mathrm{ml} \text { ) } \\
& \text { Red-cell count } \quad \text {. 2,000,000/c.mm. (range 1,300,000-2,900,000/c.mm.) } \\
& \text { Serum vitamin } \mathrm{B}_{12} \ldots 1.6 \mathrm{~m} \mu \mathrm{g} . / \mathrm{ml} \text {. (range } 0.7-3.2 \mathrm{ml} \mu \mathrm{g} . / \mathrm{ml} \text {.) }
\end{aligned}
$$


TABLE III.-Haematological Response to $200 \mu \mathrm{g}$. of Folic Acid Daily Intramuscularly

\begin{tabular}{|c|c|c|c|c|c|c|c|c|c|c|c|c|c|c|c|}
\hline \multirow{2}{*}{ No. } & \multicolumn{2}{|c|}{$\begin{array}{c}\text { Reticulocyte } \\
\text { Response }\end{array}$} & \multirow{2}{*}{ Day } & \multicolumn{3}{|c|}{ Hb Response on Day: } & \multicolumn{3}{|c|}{ R.B.C. Response on Day: } & \multicolumn{3}{|c|}{ Serum Folate on Day : } & \multicolumn{3}{|c|}{ Serum Vitamin $B_{12}$ on Day: } \\
\hline & Init. & Peak & & 0 & 14 & 28 & 0 & 14 & 28 & 0 & 14 & 28 & $\mathbf{0}$ & 14 & 28 \\
\hline $\begin{array}{r}2 \\
28 \\
10 \\
11 \\
19 \\
30 \\
26 \\
22 \\
6 \\
23 \\
27\end{array}$ & $\begin{array}{l}0.1 \\
3.8 \\
2.0 \\
0.6 \\
3.0 \\
0.8 \\
3.0 \\
1.4 \\
1.6 \\
1.1 \\
0.7\end{array}$ & $\begin{array}{r}17.0 \\
15.0 \\
26.0 \\
20.0 \\
10.9 \\
5.1 \\
5.7 \\
7.5 \\
6.9 \\
7.0 \\
5.0\end{array}$ & $\begin{array}{r}10 \\
10 \\
9 \\
7 \\
10 \\
9 \\
7 \\
8 \\
6 \\
8 \\
18\end{array}$ & $\begin{array}{r}7.9 \\
7.9 \\
8.3 \\
8.3 \\
9.8 \\
10.8 \\
10.8 \\
11.5 \\
11.8 \\
12.1 \\
10.8\end{array}$ & $\begin{array}{r}9.9 \\
11.7 \\
9.1 \\
10.8 \\
10.4 \\
12.5 \\
12.8 \\
12.0 \\
13.3 \\
14.1 \\
11.1\end{array}$ & $\begin{array}{l}11.5 \\
\overline{11.9} \\
12.6 \\
= \\
\overline{13.3} \\
13.6 \\
\frac{12.7}{12.7}\end{array}$ & $\begin{array}{l}2.1 \\
2.0 \\
2.2 \\
2.0 \\
2.3 \\
3.3 \\
2.2 \\
3.5 \\
2.3 \\
3.0 \\
2.5\end{array}$ & $\begin{array}{l}3.1 \\
3.0 \\
2.3 \\
2.8 \\
3.5 \\
3.9 \\
3.4 \\
2.9 \\
3.0 \\
3.3\end{array}$ & $\begin{array}{l}4.1 \\
3.5 \\
3.6 \\
4.0 \\
3.7 \\
4 \cdot 0 \\
4.2 \\
3.7\end{array}$ & $\begin{array}{l}1.7 \\
2.0 \\
1.6 \\
1.2 \\
1.1 \\
1.0 \\
2.6 \\
2.0 \\
2.2 \\
1.1\end{array}$ & $\begin{array}{r}\overline{3.6} \\
\overline{5.0} \\
5.5 \\
\overline{4.4} \\
12.5 \\
3.2 \\
\frac{1.9}{4.9}\end{array}$ & $\begin{array}{l}32 \\
32 \\
32 \\
32 \\
\overline{5} \cdot 8 \\
32 \\
32 \\
32 \\
32 \\
11.6\end{array}$ & $\begin{array}{r}75 \\
285 \\
210 \\
155 \\
285 \\
140 \\
575 \\
220 \\
\overline{255}\end{array}$ & $\begin{array}{l}\bar{Z} \\
195 \\
\bar{\Xi} \\
\overline{130} \\
\overline{275} \\
=\end{array}$ & $\begin{array}{l}125 \\
250 \\
290 \\
300 \\
280 \\
130 \\
\overline{100} \\
\frac{290}{1}\end{array}$ \\
\hline
\end{tabular}

Thus in most of these patients the megaloblastic anaemia was proved to be due to folate deficiency. The cause of the failure of three to respond is not clear. It is of interest that in two of these patients who failed to respond steatorrhoea continued unabated.

\section{Discussion}

On the whole the degree of anaemia was not severe in male patients, of whom only 3 out of 21 had a haemoglobin of less than $10 \mathrm{~g} . / 100 \mathrm{ml}$. As might be expected anaemia was more common and more severe in women, and 11 out of 19 had haemoglobin concentrations of less than 10 g. $/ 100 \mathrm{ml}$. Nevertheless megaloblastic change was found in every bone-marrow, approximately half showing frank megaloblastic change and half mild megaloblastic change. Dacie and White (1949) pointed out that the degree of megaloblastic change and the extent to which cells deviate from normal are closely linked with the severity of the lack of haemopoietic factor. Herbert (1959) found intermediate megaloblasts and large myelocytes in the bone-marrow at the earliest stage that folate or vitamin$B_{12}$ deficiency could be recognized haematologically. Mollin (1959) stated that when there are minor deficiencies in vitamin $B_{12}$ or folic acid intermediate megaloblastic change is the characteristic marrow reaction and that only such change may be expected when the haemoglobin level is above $8-9 \mathrm{~g} . / 100$ $\mathrm{ml}$. and the red-cell count over $3,000,000$. That the megaloblastic change was due to folate deficiency was shown by the response to small doses of folic acid and the lack of response to small doses of vitamin $B_{12}$.

These patients also suffered from malabsorption of vitamin $B_{12}$, and this was reflected in the serum levels of this vitamin even at an early stage of the disease. In two patients with severe megaloblastic anaemia there was a rapid rise in serum vitamin $B_{12}$ coincidental with a brisk haematological response to folic acid. These two patients thus resembled those of Mollin and Ross (1957), and the low serum vitamin- $B_{12}$ levels were thus partly at least due to folate deficiency. This explanation could not account for the low levels in other patients. The megaloblastic anaemia, however, was not due to vitamin- $B_{12}$ deficiency in acute tropical sprue.

Folate deficiency has long been recognized in tropical sprue. Girdwood (1948) suspected that the megaloblastic anaemia he had seen in Indian soldiers with a sprue-like syndrome was due to folic acid deficiency. In 1953 Girdwood demonstrated malabsorption of folic acid in sprue. Herbert (1962) showed that an individual on a folate-free diet developed megaloblastic change in the bone-marrow and a low serum within 23 days. It would not be surprising, therefore, if intestinal malabsorption of folate resulted in rapid folate deficiency. In many of these patients, however, there was evidence, which we hope to present at a later date, that folate deficiency preceded the onset of sprue.

\section{Summary}

The results of haematological investigation of 40 patients with acute tropical sprue are described.

The degree of anaemia varied, being mild in men and more severe in women. Every marrow showed evidence of megalo- blastic change. In half there was mild megaloblastic change and in half frank megaloblastic change.

The level of serum folate activity was reduced in every patient to a level consistent with megaloblastic anaemia. There was a full haematological response in most patients to very small doses of folic acid. The megaloblastic anaemia was thought to be due to folate deficiency.

Every patient had malabsorption of vitamin $B_{12}$, and this was reflected in reduced serum levels of this vitamin. At this early stage in the disease, however, the megaloblastic change was not thought to be due to this deficiency.

We thank the Director-General of Medical Services for permission to publish this paper. This work was financed by the Wellcome Trust, to whom we are grateful for generous assistance. Dr. D. L. Mollin and Dr. C. C. Booth, of the Postgraduate Medical School, Hammersmith, have given us their constant help and advice at all stages of this work. We also thank Brigadier M. H. P. Sayers and Colonel R. L. Marks for their support and encouragement, and Dr. Leon Ellenbogen, of Lederle Laboratories, Pearl River, N.Y., for the supply of intrinsic factor.

\section{REFERENCES}

Castle, W. B., Rhoads, C. P., Lawson, H. A., and Payne, G. C. (1935). Arch. intern. Med., 56, 627.

Crosby, W. H., and Kugler, H. W. (1957). Amer. F. dig. Dis., 2, 236. Drosie, J. V. (1956). Practical Haematology, 2nd ed. Churchill, London. Dacie, J. V. (1956). Practical Haematology, 2nd ed.

Fairley, N. H. (1932). Proc. roy. Soc. Med., 25, 1708.

Gardner, F. H. (1960). Amer. F. clin. Nutr., 8, 179

Girdwood, R. H. (1948). Trans. roy. Soc. trop. Med. Hyg., 42, 65.

(1953). Lancet, 2, 53 .

Glass, G. B. J., Boyd, L. J., Gellin, G. A., and Stephanson, L. (1954). Arch. Biochem., 51, 251.

Heinle, R. W., Welch, A. D., Scharf, V., Meacham, G. C., and Prusoff, W. H. (1952). Trans. Ass. Amer. Phycns, 65, 214.

Herbert, V. D. (1959). The Megaloblastic Anaemias, p. 6. Grune, and Stratton, London.

- (1962). Trans. Ass. Amer. Phycns, 75, 307

Hutner, S. H., Bach, M. K., and Ross, G. I. M. (1956). F. Protozool., 3,101 .

Kay, A. W. (1953). Brit. med. F., 2, 77.

Mackie, F. P. and Fairley, N. H., (1929). Indian f. med. Res., 16, 799.

Manie, P. (1879-80). China Imp. Customs med. Rep., 19, 33.

Marriott, H. L. (1945). Lancet, $1,679$.

Mollin, D. L. (1959). Brit. med. \%., 1, 302.

- (1961). Trans. med. Soc. Lond., 78, 51.

- and Ross, G. I. M. (1954). Proc. roy. Soc. Med., 47, 428. (1957). Vitamin $B_{12}$ and Intrinsic Factor, 1 Europ. Symp. Hamburg, 1956, p. 413. Enke, Stuttgart.

Perez-Santiago, E., and Butterworth, C. E. (1957). Amer. ¥. dig. Dis., 2,

Rhoads, C. P., and Miller, D. K. (1934). 7. Amer. med. Ass., $103,387$.

Rhoads, C. P., and Mernabe Prida, R. (1962). Amer. F. trop. Med. Hyg. 11,718 .

Rodriguez-Molina, R. (1939). Puerto Rico f. publ. Hlth, 15, 89.

Rodriguez-Rosado, A. L., and Sheehy, T. W. (1961). Amer. F. med. Sci., 242, 548.

Santini, R., Sheehy, T. W., and Martinez-de Jesus, J. (1961). Gastro-

enterology, 40, 772 .
Sheehy, T. W., Perez-Santiago, E., and Rubini, M. E. (1961a). New

Engl. F. Med.., 265, 1232. (1961b). Blood, 18, 623 .

Spies, T. D., Garcia Lopez, G., Menendez, J. A., Minnich, V., and Koch, M. B. (1946). Sth. med. 手. (Bgham, Ala.), 39, 30.

Suárez, R. M., Spies, T. D., and Suárez, R. M., jun. (1947). Ann. intern. Med., 26, 643.

Thin, G. (1897). Psilosis or Sprue. Churchill, London.

van de Kamer, J. H., Huinink, H. ten B., and Weyers, H. A. (1949). J. biol. Chem., 177, 347.

Waters, A. H., and Mollin, D. L. (1961). 7. clin. Path., 14, 335. 